\title{
Aminobacter ciceronei sp. nov. and Aminobacter lissarensis sp. nov., isolated from various terrestrial environments
}

\author{
Ian R. McDonald, ${ }^{1} \dagger$ Peter Kämpfer, ${ }^{2}$ Ed Topp, ${ }^{3}$ Karen L. Warner, ${ }^{1}$ \\ Michael J. Cox, ${ }^{1}$ Tracy L. Connell Hancock, ${ }^{4}$ Laurence G. Miller, ${ }^{4}$ \\ Michael J. Larkin, ${ }^{5}$ Veronique Ducrocq, ${ }^{5}$ Catherine Coulter, ${ }^{6}$ \\ David B. Harper, ${ }^{6}$ J. Colin Murrell ${ }^{1}$ and Ronald S. Oremland ${ }^{4}$ \\ ${ }^{1}$ Department of Biological Sciences, University of Warwick, Coventry CV4 7AL, UK \\ ${ }^{2}$ Institut für Angewandte Mikrobiologie, Justus-Liebig-Universität Giessen, D-35390 Giessen, \\ Germany \\ ${ }^{3}$ Agriculture and Agri-Food Canada, London, Ontario, Canada N5V 4T3 \\ ${ }^{4}$ US Geological Survey, 345 Middlefield Rd, MS 480, Menlo Park, CA 94025, USA \\ ${ }^{5}$ Questor Centre, Queen's University Belfast, Belfast BT9 5AG, UK \\ ${ }^{6}$ School of Agriculture and Food Science, Queen's University Belfast, Newforge Lane, Belfast \\ BT9 5PX, UK
}

Correspondence lan R. McDonald i.mcdonald@waikato.ac.nz
The bacterial strains IMB- $1^{\top}$ and $\mathrm{CC} 495^{\top}$, which are capable of growth on methyl chloride $\left(\mathrm{CH}_{3} \mathrm{Cl}\right.$, chloromethane) and methyl bromide $\left(\mathrm{CH}_{3} \mathrm{Br}\right.$, bromomethane), were isolated from agricultural soil in California fumigated with $\mathrm{CH}_{3} \mathrm{Br}$, and woodland soil in Northern Ireland, respectively. Two pesticide-/herbicide-degrading bacteria, strains ER2 and C147, were isolated from agricultural soil in Canada. Strain ER2 degrades $N$-methyl carbamate insecticides, and strain C147 degrades triazine herbicides widely used in agriculture. On the basis of their morphological, physiological and genotypic characteristics, these four strains are considered to represent two novel species of the genus Aminobacter, for which the names Aminobacter ciceronei sp. nov. (type strain $\mathrm{IMB}-1^{\top}=$ ATCC $202197^{\top}=\operatorname{CIP} 108660^{\top}=$ CCUG $50580^{\top}$; strains ER2 and C147) and Aminobacter lissarensis sp. nov. (type strain $\mathrm{CC} 495^{\top}=\mathrm{NCIMB} 13798^{\top}=\mathrm{CIP} 108661^{\top}=$ CCUG $50579^{\top}$ ) are proposed.
The genus Aminobacter was proposed following the transfer of Pseudomonas aminovorans den Dooren de Jong 1926 to Aminobacter aminovorans (Urakami et al., 1992). At the same time, two novel species were described, Aminobacter aganoensis and Aminobacter niigataensis (Urakami et al., 1992). More recently, the closely related species Chelatobacter heintzii (Auling et al., 1993) was also shown to be a member of the genus Aminobacter, as a later heterotypic (formerly subjective) synonym of Aminobacter aminovorans (Kämpfer et al., 2002).

The facultatively methylotrophic strain IMB- $1^{\mathrm{T}}$ was isolated

Published online ahead of print on 22 April 2005 as DOI 10.1099/ ijs.0.63716-0.

tPresent address: Department of Biological Sciences, University of Waikato, Private Bag 3105, Hamilton, New Zealand.

The GenBank/EMBL/DDBJ accession numbers for the 16S rRNA gene sequences of strains IMB-1 $1^{\top}$, ER2, C147 and $\mathrm{CC}_{4} 45^{\top}$ are AF034798, L20802, AF246220 and AF107722, respectively. from $\mathrm{CH}_{3} \mathrm{Br}$-fumigated soil collected in Irvine, CA, USA (Connell Hancock et al., 1998; Miller et al., 1997), and was initially phylogenetically characterized based on $16 \mathrm{~S}$ rRNA gene sequence analysis as being closely related to members of the genus Rhizobium in the 'Alphaproteobacteria'. Strain IMB- $1^{\mathrm{T}}$ was able to grow on $\mathrm{C}_{1}$ compounds such as $\mathrm{CH}_{3} \mathrm{Cl}$, $\mathrm{CH}_{3} \mathrm{Br}, \mathrm{CH}_{3} \mathrm{I}$ and methylated amines as sole carbon and energy sources but was not able to grow on $\mathrm{CH}_{3} \mathrm{~F}$. Growth also occurred on glucose, acetate and pyruvate; some growth was observed with low levels of methanol (Connell Hancock et al., 1998). No growth or oxidation was observed with methane, formate, propyl iodide, dibromomethane, dichloromethane or difluoromethane (Connell Hancock et al., 1998; Miller et al., 1997; Schaefer \& Oremland, 1999). Oxidation of $\mathrm{CH}_{3} \mathrm{Br}$ in soil was greatly enhanced by addition of $\mathrm{CH}_{3} \mathrm{Br}$-grown cells of strain IMB- ${ }^{\mathrm{T}}$ to the soil (Connell Hancock et al., 1998).

The facultatively methylotrophic strain $\mathrm{CC} 495^{\mathrm{T}}$ was isolated from the soil of a beech woodland at Lissara House, near 
Crossgar, County Down, Northern Ireland. Phylogenetic analysis of its $16 \mathrm{~S}$ rRNA gene sequence indicated that, as with strain IMB-1 ${ }^{\mathrm{T}}$, it was closely associated with the genus Rhizobium (Coulter et al., 1999). Strain $\mathrm{CC}^{2} 5^{\mathrm{T}}$, in the presence of cyanocobalamin, was able to grow on $\mathrm{CH}_{3} \mathrm{Cl}$ and $\mathrm{CH}_{3} \mathrm{Br}$ as sole carbon and energy sources but was not able to utilize either $\mathrm{CH}_{3} \mathrm{I}$ or $\mathrm{CH}_{3} \mathrm{~F}$. However, oxidation of $\mathrm{CH}_{3} \mathrm{I}$ by $\mathrm{CH}_{3} \mathrm{Cl}$-grown cell suspensions was observed. Growth also occurred on methylamine, for which no supplementation of the medium by cyanocobalamin was required (Coulter et al., 1999). The $\mathrm{C}_{1}$ compounds methanol, methane, formaldehyde, formate, methane thiol and dichloromethane did not act as growth substrates, although formate, formaldehyde and methane thiol were oxidized by $\mathrm{CH}_{3} \mathrm{Cl}$-grown cell suspensions. Strain $\mathrm{CC} 495^{\mathrm{T}}$ was able to utilize glucose, pyruvate and glycerol as sole carbon and energy sources, but not veratrate or syringate (Coulter et al., 1999). Under microaerophilic or anaerobic conditions, suspensions of $\mathrm{CH}_{3} \mathrm{Cl}$-grown cells of strain $\mathrm{CC}_{4} 95^{\mathrm{T}}$ catalysed the transhalogenation of the halomethanes $\mathrm{CH}_{3} \mathrm{Cl}, \mathrm{CH}_{3} \mathrm{Br}$ and $\mathrm{CH}_{3}$ I, i.e. the exchange of various halide ions with the halomethanes (Harper et al., 2000). Several other bacteria have also been isolated that utilize methyl halides as sole sources of carbon (Doronina et al., 1996; Goodwin et al., 1997). These strains have been designated Hyphomicrobium chloromethanicum $\mathrm{CM}_{2}{ }^{\mathrm{T}}$ (McDonald et al., 2001), Methylobacterium chloromethanicum $\mathrm{CM}_{4}^{\mathrm{T}}$ (McDonald et al., 2001) and Leisingera methylohalidivorans $\mathrm{MB}^{\mathrm{T}}{ }^{\mathrm{T}}$ (Schaefer et al., 2002).

The facultatively methylotrophic strain ER2 was isolated from an agricultural soil in Canada. This strain rapidly degraded the aryl $\mathrm{N}$-methyl carbamate insecticide carbofuran (Topp et al., 1993) and was initially characterized phylogenetically as being closely related to members of the methylotrophic bacteria. Strain ER2 is able to utilize several $\mathrm{N}$-methyl carbamate insecticides as sole sources of carbon and nitrogen. The atrazine-degrading bacterial strain C147 was isolated from farm soil in Canada. It rapidly degraded the herbicide atrazine (Topp et al., 2000). Strain C147 is able to utilize atrazine and other $S$-triazine herbicides as sole sources of carbon and nitrogen. Here we report the physiological characteristics, fatty acid composition and phylogenetic characterization (based on 16S rRNA gene sequence analysis and DNA-DNA hybridization) for strains IMB-1 ${ }^{\mathrm{T}}$, CC495 ${ }^{\mathrm{T}}$, ER2 and C147.

The complete 16S rRNA gene sequences (McDonald et al., 1997) from strains IMB- $1^{\mathrm{T}}, \mathrm{CC} 495^{\mathrm{T}}$, ER2 and $\mathrm{C} 147$ were aligned, using the ARB program (Ludwig et al., 2004), to representative organisms from Aminobacter and related genera, and their phylogenetic positions were determined using the DNADIST, DNAML, DNAPARS and SEQBOOT programs of the PHYLIP package (Felsenstein, 1993). Phylogenetic dendrograms were constructed from the distance data using the Fitch-Margoliash method and the dendrograms were drawn using TreeView version 1.5 (Page, 1996). DNA-DNA hybridization was carried out using the two methods of Huß et al. (1983) and Kämpfer et al. (2002). The two methods gave comparable results, with the exception of hybridization of A. aminovorans and strain $\mathrm{CC} 495^{\mathrm{T}}$, for which repeat hybridizations gave widely differing values $(20 \cdot 8-72 \cdot 0 \%)$ in reciprocal hybridizations. These differences in reciprocal hybridization had already been detected in previous studies (Urakami et al., 1992; Kämpfer et al., 2002). This may be due to the presence of plasmids in $\mathrm{CC} 45^{\mathrm{T}}$; however, no plasmids have been detected in this strain to date.

Phenotypic characterization and fatty acid analysis were carried out as described by Kämpfer et al. (1999, 2002), and indicated that IMB-1 ${ }^{\mathrm{T}}$, ER2 and C147 were very similar at this level of characterization (Tables 1 and 2).

Phylogenetic analysis of the 16S rRNA gene sequences of strains IMB-1 ${ }^{\mathrm{T}}, \mathrm{CC} 495^{\mathrm{T}}$, ER2 and C147 (Fig. 1) showed them to be located within the genus Aminobacter (Urakami et al., 1992), as supported by bootstrap values. The $16 \mathrm{~S}$ rRNA gene of strain IMB- $1^{\mathrm{T}}$ had high sequence similarity with A. aminovorans DSM $7048^{\mathrm{T}}(99 \cdot 6 \%)$, A. aganoensis DSM $7051^{\mathrm{T}}(99 \cdot 6 \%)$, A. niigataensis DSM $7050^{\mathrm{T}}(99 \cdot 6 \%)$, C147 (99.6\%) and ER2 (97.8\%). Analysis of the $16 \mathrm{~S}$ rRNA gene sequence of strain $C C 495^{\mathrm{T}}$ showed it to be most closely related to A. aminovorans (99.3 \%), A. aganoensis (99.2\%) and A. niigataensis $(99 \cdot 2 \%)$. The $16 \mathrm{~S}$ rRNA gene of strain ER2 had high sequence similarity with $A$. aganoensis DSM $7051^{\mathrm{T}}(97 \cdot 9 \%)$, A. niigataensis DSM $7050^{\mathrm{T}}(97 \cdot 9 \%)$, IMB- $1^{\mathrm{T}}(97 \cdot 8 \%), \mathrm{CC} 45^{\mathrm{T}}(97 \cdot 8 \%), \mathrm{C} 147(97 \cdot 8 \%)$ and $A$. aminovorans DSM $7048^{\mathrm{T}}(97 \cdot 7 \%)$. Analysis of the $16 \mathrm{~S}$ rRNA gene sequence of strain C147 showed it to be most closely related to A. aganoensis DSM $7051^{\mathrm{T}}(99 \cdot 6 \%)$, A. niigataensis DSM $7050^{\mathrm{T}}(99 \cdot 6 \%), \mathrm{IMB}^{\mathrm{T}}(99 \cdot 6 \%), A$. aminovorans DSM $7048^{\mathrm{T}}(99 \cdot 5 \%)$ and CC495 ${ }^{\mathrm{T}}(98 \cdot 9 \%)$.

The previously characterized strains of Aminobacter ( $A$. aminovorans DSM $7048^{\mathrm{T}}$, A. niigataensis DSM $7050^{\mathrm{T}}$ and A. aganoensis DSM $7051^{\mathrm{T}}$ ) and strains ER2 (Topp et al., 1993) and C147 (Topp et al., 2000) were tested for their ability to grow on $\mathrm{CH}_{3} \mathrm{Cl}$ or $\mathrm{CH}_{3} \mathrm{Br}$, and then screened by Southern probing and PCR for the presence of genes that code for enzymes involved in degradation of methyl halides (McDonald et al., 2002). However, all strains tested negative, indicating that strains IMB- $1^{\mathrm{T}}$ and $\mathrm{CC} 495^{\mathrm{T}}$ are distinct from the other Aminobacter species, representing the only species able to grow on $\mathrm{CH}_{3} \mathrm{Cl}$ or $\mathrm{CH}_{3} \mathrm{Br}$. The previously characterized Aminobacter species (A. aminovorans, A. niigataensis, A. aganoensis) and IMB $-1^{\mathrm{T}}$ and $\mathrm{CC} 495^{\mathrm{T}}$ were tested for the ability to degrade atrazine or carbofuran by HPLC analysis of cell suspensions incubated in mineral salts medium. Degradation was tested with the substrate as sole carbon and nitrogen sources in the absence of glucose, or as a sole nitrogen source in the presence of glucose, which supports growth as determined by turbidity. No degradation was detected for any of the strains tested. PCR amplification of genomic DNA using gene-specific primers also indicated that none of the strains possessed the genes atzA (atrazine chlorohydrolase) (de Souza et al., 1996) or $m c d$ 
Table 1. Physiological characteristics of the type strains of Aminobacter species

+, Positive; -, negative; $(+)$ weakly positive; pNP, para-nitrophenyl; pNA, para-nitroanilide. Test results given in the table were read after $72 \mathrm{~h}$ of incubation at $30^{\circ} \mathrm{C}$. All seven strains were positive for the following: utilization of $\mathrm{N}$-acetyl-D-glucosamine, L-arabinose, D-cellobiose, D-fructose, D-galactose, D-glucose, D-mannose, D-maltose, D-ribose, D-xylose, i-inositol, D-mannitol, D-sorbitol, acetate, 4-aminobutyrate, DL-3-hydroxybutyrate, DL-lactate, oxoglutarate, L-alanine, L-aspartate, L-histidine, L-leucine, L-ornithine, L-proline and L-serine, and hydrolysis of bis-pNP-phosphate, pNP-phenyl phosphonate, L-alanine-pNA and L-proline-pNA. All seven strains were negative for the following: utilization of $p$-arbutin, $\alpha$-D-melibiose, salicin, adonitol, maltitol, putrescine, cis-aconitate, trans-aconitate, adipate, azelate, citrate, fumarate, itaconate, mesaconate, suberate, L-phenylalanine, 3-hydroxybenzoate and phenylacetate, hydrolysis of aesculin, pNP $\beta$-D-galactopyranoside, pNP $\beta$-D-glucuronide, 2-deoxythymidine-5'-pNP phosphate and L-glutamate $\gamma$-3-carboxy-pNA and acid production from lactose, adonitol, rhamnose, methyl D-glucoside, erythritol and melibiose.

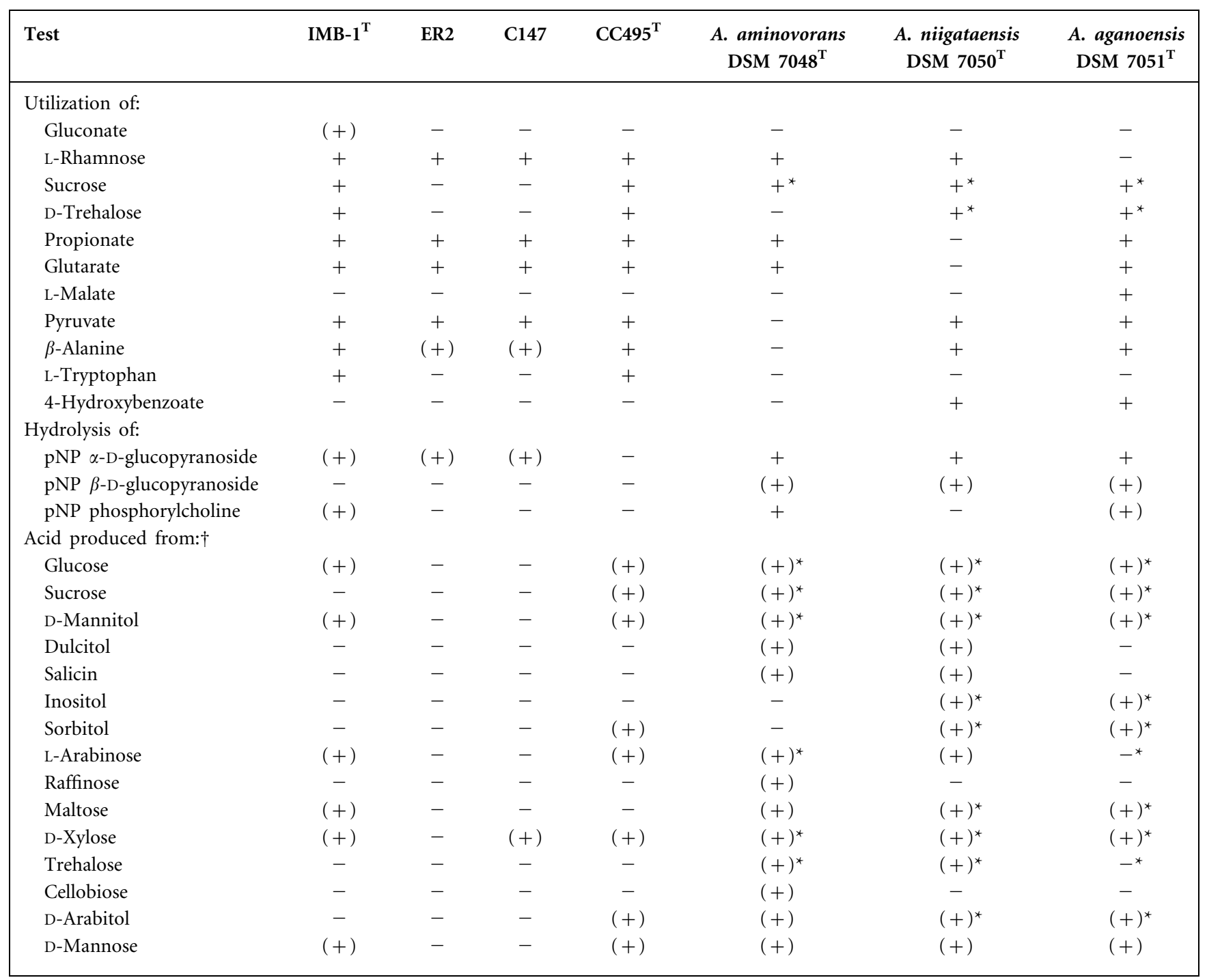

${ }^{\star}$ Data are in line with those published by Urakami et al. (1992).

$\dagger$ Acid formation from carbohydrates in most cases was very weak (even after prolonged incubation). These tests cannot be recommended for differentiation.

(methylcarbamate hydrolase) (Tomasek \& Karns, 1989). These genes were found in strains ER2 and C147, respectively, and are widely found in other Gram-negative bacteria that degrade atrazine or carbofuran. Therefore, there is no evidence for the degradation of atrazine or carbofuran by any of the other characterized Aminobacter species. This ability of strains ER2 and C147 to degrade atrazine or carbofuran is therefore unique among the Aminobacter species.

The result of genotypic and phenotypic investigations justify the proposal of two novel Aminobacter species. 
Table 2. Major fatty acid compositions of type strains of species of the genus Aminobacter

Values are percentages of total fatty acids. All strains were grown on trypticase soy broth agar at $28{ }^{\circ} \mathrm{C}$ for $48 \mathrm{~h}$ prior to fatty acid analysis. For unsaturated fatty acids, the position of the double bond is located by counting from the methyl $(\omega)$ end of the carbon chain; cis and trans isomers are indicated by the suffixes $c$ and $t$, respectively. Summed features are groups of two or three fatty acids that cannot be separated by GLC with the MIDI system. Summed feature 4 contains $16: 1 \omega 7 c$ and/or 15:0 iso 2-OH; summed feature 7 contains $18: 1 \omega 7 c$, $18: 1 \omega 9 t$ and/or 18:1 $1 \omega 12 t$. Unknown fatty acids have no name listed in the peak library file of the MIDI system and therefore cannot be identified.

\begin{tabular}{|c|c|c|c|c|c|c|c|}
\hline Compound & IMB-1 ${ }^{\mathrm{T}}$ & ER2 & C147 & $\mathrm{CC} 495^{\mathrm{T}}$ & $\begin{array}{c}\text { A. aminovorans } \\
\text { DSM } 7058^{\mathrm{T}}\end{array}$ & $\begin{array}{c}\text { A. niigataensis } \\
\text { DSM } 7050^{\mathrm{T}}\end{array}$ & $\begin{array}{c}\text { A. aganoensis } \\
{\text { DSM } 7051^{\mathrm{T}}}\end{array}$ \\
\hline \multicolumn{8}{|l|}{ Saturated fatty acids: } \\
\hline $9: 0$ & $1 \cdot 1$ & & & & $1 \cdot 0$ & & \\
\hline $16: 0$ & $5 \cdot 7$ & $6 \cdot 8$ & $6 \cdot 5$ & $8 \cdot 9$ & $4 \cdot 9$ & $6 \cdot 0$ & $6 \cdot 2$ \\
\hline $17: 0$ & $1 \cdot 0$ & & $0 \cdot 7$ & & $0 \cdot 7$ & & \\
\hline $18: 0$ & $2 \cdot 9$ & $5 \cdot 0$ & $4 \cdot 4$ & $3 \cdot 3$ & $1 \cdot 5$ & $2 \cdot 0$ & $2 \cdot 0$ \\
\hline $20: 0$ & $0 \cdot 3$ & $0 \cdot 7$ & $0 \cdot 5$ & & & & \\
\hline \multicolumn{8}{|l|}{ Unsaturated fatty acids: } \\
\hline $15: 1 \omega 8 c$ & & & & & & & $1 \cdot 3$ \\
\hline $17: 1 \omega 8 c$ & $0 \cdot 6$ & & & & $0 \cdot 7$ & & \\
\hline \multicolumn{8}{|l|}{$17: 1 \omega 6 c$} \\
\hline 11-Methyl $18: 1 \omega 7 t$ & $18 \cdot 9$ & $14 \cdot 3$ & $13 \cdot 4$ & $10 \cdot 5$ & & & \\
\hline $19: 1 \omega 12 t$ & & & & & $1 \cdot 3$ & & \\
\hline $20: 0 \omega 6,9 c$ & $0 \cdot 6$ & & & & & & \\
\hline $20: 1 \omega 9 t$ & $0 \cdot 6$ & $1 \cdot 0$ & $0 \cdot 9$ & & $0 \cdot 8$ & $0 \cdot 7$ & \\
\hline \multicolumn{8}{|l|}{ Branched fatty acids: } \\
\hline $15: 0 \mathrm{i}$ & & & & & & $3 \cdot 1$ & $2 \cdot 9$ \\
\hline $17: 0 \mathrm{i}$ & $2 \cdot 4$ & $2 \cdot 9$ & $2 \cdot 4$ & $2 \cdot 4$ & $1 \cdot 0$ & $3 \cdot 0$ & $4 \cdot 8$ \\
\hline $19: 0 \mathrm{i}$ & & & $0 \cdot 5$ & & & & \\
\hline \multicolumn{8}{|l|}{ Hydroxy fatty acids: } \\
\hline $12: 03-\mathrm{OH}$ & $0 \cdot 4$ & $0 \cdot 4$ & $0 \cdot 3$ & $0 \cdot 3$ & $0 \cdot 3$ & $0 \cdot 4$ & $0 \cdot 4$ \\
\hline $15: 0 \mathrm{i} 3-\mathrm{OH}$ & & & & & & & \\
\hline \multicolumn{8}{|l|}{ Summed features: } \\
\hline Summed feature 4 & $0 \cdot 5$ & & & & $0 \cdot 5$ & $1 \cdot 0$ & $1 \cdot 1$ \\
\hline Summed feature 7 & $59 \cdot 1$ & $52 \cdot 7$ & $54 \cdot 7$ & $69 \cdot 8$ & $46 \cdot 4$ & $48 \cdot 6$ & $64 \cdot 8$ \\
\hline \multicolumn{8}{|l|}{ Cyclopropane acids: } \\
\hline $17: 0$ cyclo & & & & & $0 \cdot 5$ & & \\
\hline $19: 0$ cyclo $\omega 8 c$ & $5 \cdot 6$ & $15 \cdot 3$ & $14 \cdot 3$ & $5 \cdot 0$ & $13 \cdot 7$ & $10 \cdot 3$ & $4 \cdot 7$ \\
\hline Unknown $14 \cdot 966$ & $1 \cdot 0$ & $0 \cdot 8$ & $0 \cdot 9$ & & $0 \cdot 7$ & & \\
\hline Unknown $18 \cdot 081$ & & & & & $24 \cdot 8$ & $21 \cdot 0$ & $10 \cdot 9$ \\
\hline Unknown $18 \cdot 597$ & & & & & $0 \cdot 5$ & $1 \cdot 8$ & $0 \cdot 8$ \\
\hline Unknown $18 \cdot 804$ & & & & & $0 \cdot 4$ & $0 \cdot 7$ & \\
\hline
\end{tabular}

\section{Description of Aminobacter ciceronei sp. nov.}

Aminobacter ciceronei (cic.er.one'i. N.L. gen. n. ciceronei of Cicerone, named after Professor Ralph Cicerone, an American atmospheric chemist who has made many seminal contributions to our understanding of the chemistry of atmospheric trace gases, with particular reference to his work on the biogeochemistry of methyl halides).

Gram-negative, rod-shaped cells. Cells are $0.6 \mu \mathrm{m}$ in diameter and $1 \cdot 3 \mu \mathrm{m}$ long. Cells are motile and nonpigmented. Growth is aerobic. Grows on $\mathrm{CH}_{3} \mathrm{Br}, \mathrm{CH}_{3} \mathrm{Cl}$, $\mathrm{CH}_{3} \mathrm{I}$ and methylamine as sole carbon and energy sources. Further physiological features are given in Table 1. The main fatty acids are $\mathrm{C}_{16: 0}$ and $\mathrm{C}_{18: 1}$ (see Table 2). Optimum temperature for growth is $28-30{ }^{\circ} \mathrm{C}$. Optimum $\mathrm{pH}$ for growth is $6 \cdot 5-7 \cdot 5$. G $+\mathrm{C}$ content of the DNA is $62 \cdot 0-$ $63 \cdot 7 \mathrm{~mol} \%$. Levels of DNA-DNA relatedness to representatives of the genus Aminobacter are indicated in Table 3.

The type strain, IMB- $1^{\mathrm{T}}\left(=\mathrm{ATCC} 202197^{\mathrm{T}}=\mathrm{CIP} 108660^{\mathrm{T}}\right.$ $=$ CCUG $50580^{\mathrm{T}}$ ), was isolated from $\mathrm{CH}_{3} \mathrm{Br}$-fumigated agricultural soil at Irvine, CA, USA. Strain ER2 was isolated from soil from Prince Edward Island (Canada) that was enriched with carbofuran-degrading micro-organisms by perfusing it continuously for 4 months with distilled water containing $100 \mathrm{mg}$ carbofuran $\mathrm{l}^{-1}$; strain C147 was isolated from a loam soil from a site near Ottawa, Ontario, Canada. 


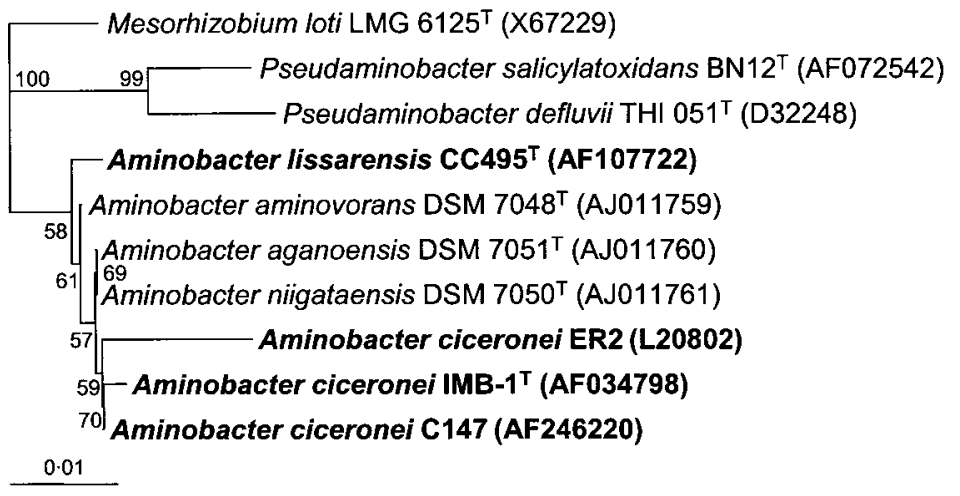

Fig. 1. Phylogenetic analysis of the $16 \mathrm{~S}$ rRNA gene sequences of Aminobacter ciceronei sp. nov. strains IMB-1 ${ }^{\top}$, ER2 and C147, Aminobacter lissarensis sp. nov. $\mathrm{CC}_{495}{ }^{\top}$, other Aminobacter strains and related genera. The dendrogram shows the results of an analysis in which DNADIST was used. Bootstrap values greater than $50 \%$ derived from 100 replicates are also shown. Bar, $1 \%$ sequence divergence, as determined by measuring the lengths of the horizontal lines connecting any two species.

\section{Description of Aminobacter lissarensis sp. nov.}

Aminobacter lissarensis (liss.ar.en'sis. N.L. masc. adj. lissarensis pertaining to Lissara House in Northern Ireland, where the type strain was isolated).

Gram-negative, rod-shaped cells, $0 \cdot 5-0 \cdot 6 \mu \mathrm{m}$ in diameter and $1 \cdot 3-1 \cdot 5 \mu \mathrm{m}$ long. Cells are motile and faintly pinkpigmented. Growth is aerobic. Grows on $\mathrm{CH}_{3} \mathrm{Cl}$ and $\mathrm{CH}_{3} \mathrm{Br}$ as sole carbon and energy sources in the presence of cyanocobalamin $\left(1 \mathrm{mg} \mathrm{l}^{-1}\right)$. Methyl amine, glucose, pyruvate and glycerol also act as growth substrates without a requirement for supplementation of the medium with cyanocobalamin. $\mathrm{C}_{1}$-compound assimilation is via the serine pathway. Further physiological features are given in Table 1 . The main fatty acid is $\mathrm{C}_{18: 1}$. Optimum temperature for growth is $25^{\circ} \mathrm{C}$. Optimum $\mathrm{pH}$ for growth is $6 \cdot 7-7 \cdot 2$. $\mathrm{G}+\mathrm{C}$ content of the DNA is $62.5 \mathrm{~mol} \%$. Levels of DNADNA hybridization of the type strain to representatives of the genus Aminobacter are indicated in Table 3.

The type strain, CC $495^{\mathrm{T}}\left(=\mathrm{NCIMB} 13798^{\mathrm{T}}=\mathrm{CIP} 108661^{\mathrm{T}}\right.$

Table 3. DNA-DNA hybridization values between members of the genera Aminobacter

Mean values of at least two hybridizations are given. ND, Not determined.

\begin{tabular}{|lccccccc|}
\hline \multirow{2}{*}{$\begin{array}{l}\text { Source of } \\
\text { unlabelled DNA }\end{array}$} & \multicolumn{7}{c|}{ Source of labelled DNA } \\
\cline { 2 - 8 } & $\mathbf{1}$ & $\mathbf{2}$ & $\mathbf{3}$ & $\mathbf{4}$ & $\mathbf{5}$ & $\mathbf{6}$ & $\mathbf{7}$ \\
\hline 1. Strain IMB-1 $^{\mathrm{T}}$ & 100 & $87 \cdot 7$ & $99 \cdot 0$ & $44 \cdot 3$ & $47 \cdot 7$ & $37 \cdot 2$ & $17 \cdot 9$ \\
2. Strain ER2 & $>100$ & 100 & $55 \cdot 7$ & $\mathrm{ND}$ & $38 \cdot 3$ & $48 \cdot 7$ & $13 \cdot 0$ \\
3. Strain C147 & $80 \cdot 0$ & $\mathrm{ND}$ & 100 & $\mathrm{ND}$ & $34 \cdot 3$ & $40 \cdot 2$ & $37 \cdot 4$ \\
4. Strain CC495 & $\mathrm{ND}$ & $\mathrm{ND}$ & $\mathrm{ND}$ & 100 & $20 \cdot 8$ & $49 \cdot 5$ & $31 \cdot 8$ \\
5. A. aminovorans & $33 \cdot 0$ & $43 \cdot 8$ & $56 \cdot 6$ & $\mathrm{ND}$ & 100 & $45 \cdot 0^{*}$ & $58 \cdot 0^{*}$ \\
DSM 7048 & & & & & & & \\
6. A. aganoensis & $20 \cdot 3$ & $35 \cdot 8$ & $32 \cdot 9$ & $28 \cdot 6$ & $55^{*}$ & 100 & $60 \cdot 0^{*}$ \\
DSM 7051 & & & & & & & \\
7. A. niigataensis & $14 \cdot 7$ & $37 \cdot 0$ & $32 \cdot 9$ & $16 \cdot 4$ & $\mathrm{ND}$ & $66^{*}$ & 100 \\
DSM 7050 & & 7 & & & & \\
\hline
\end{tabular}

${ }^{*}$ Data from Kämpfer et al. (2002).
$=$ CCUG $50579^{\mathrm{T}}$ ), was isolated from an unpolluted beech woodland soil in County Down, Northern Ireland.

\section{Acknowledgements}

We acknowledge financial support provided by the Natural Environment Research Council (UK) for $\mathrm{PhD}$ studentships to K.L.W. and M.J.C., and for an advanced research fellowship to I. R. M. Thanks to Jean Euzéby for advice on naming of the bacterial strains.

\section{References}

Auling, G., Busse, H. J., Egli, T., El-Banna, T. \& Stackebrandt, E. (1993). Description of the Gram-negative, obligately aerobic, nitrilotriacetate (NTA)-utilizing bacteria as Chelatobacter heintzii, gen. nov., sp. nov., and Chelatococcus asaccharovorans, gen. nov., sp. nov. Syst Appl Microbiol 16, 104-112.

Connell Hancock, T. L., Costello, A. M., Lidstrom, M. E. \& Oremland, R. S. (1998). Strain IMB-1, a novel bacterium for the removal of methyl bromide in fumigated agricultural soils. Appl Environ Microbiol 64, 2899-2905.

Coulter, C., Hamilton, J. T. G., McRoberts, W. C., Kulakov, L., Larkin, M. J. \& Harper, D. B. (1999). Halomethane: bisulfide/halide ion methyltransferase, an unusual corrinoid enzyme of environmental significance isolated from an aerobic methylotroph using chloromethane as the sole carbon source. Appl Environ Microbiol 65, 4301-4312.

den Dooren de Jong, L. E. (1926). In Bijdrage tot de kennis van het Mineralisatieproces, pp. 1-199. Thesis, Technische Hogeschool, Delft, The Netherlands (in Dutch).

de Souza, M. L., Sadowsky, M. J. \& Wackett, L. P. (1996). Atrazine chlorohydrolase from Pseudomonas sp. strain ADP: gene sequence, enzyme purification, and protein characterisation. J Bacteriol 178, 4894-4900.

Doronina, N. V., Sokolov, A. P. \& Trotsenko, Y. A. (1996). Isolation and initial characterization of aerobic chloromethane-utilizing bacteria. FEMS Microbiol Lett 142, 179-183.

Felsenstein, J. (1993). PHYLIP (Phylogenetic Interference Package), version 3.5c. Distributed by the author. Department of Genome Sciences, University of Washington, Seattle.

Goodwin, K. D., Lidstrom, M. E. \& Oremland, R. S. (1997). Marine bacterial degradation of brominated methanes. Environ Sci Technol 31, 3188-3192.

Harper, D. B., Kalin, R. N., Larkin, M. J., Hamilton, J. T. G. \& Coulter, C. (2000). Microbial transhalogenation: a complicating factor in 
determination of atmospheric chloro- and bromomethane budgets. Environ Sci Technol 34, 2525-2527.

Huß, V. A. R., Festl, H. \& Schleifer, K. H. (1983). Studies on the spectrophotometric determination of DNA hybridization from renaturation rates. Syst Appl Microbiol 4, 184-192.

Kämpfer, P., Müller, C., Mau, M., Neef, A., Auling, G., Busse, H.-J., Osborn, A. M. \& Stolz, A. (1999). Description of Pseudaminobacter gen. nov. with two new species, Pseudaminobacter salicylatoxidans sp. nov. and Pseudaminobacter defluvii sp. nov. Int J Syst Bacteriol 49, 887-897.

Kämpfer, P., Neef, A., Salkinoja-Salonen, M. S. \& Busse, H. J. (2002). Chelatobacter heintzii (Auling et al. 1993) is a later subjective synonym of Aminobacter aminovorans (Urakami et al. 1992). Int J Syst Evol Microbiol 52, 835-839.

Ludwig, W., Strunk, O., Westram, R. \& 29 other authors (2004). ARB: a software environment for sequence data. Nucleic Acids Res 32, 1363-1371.

McDonald, I. R., Kelly, D. P., Murrell, J. C. \& Wood, A. P. (1997). Taxonomic relationships of Thiobacillus halophilus, T. aquaesulis, and other species of Thiobacillus, as determined using $16 \mathrm{~S}$ rDNA sequencing. Arch Microbiol 166, 394-398.

McDonald, I. R., Doronina, N. V., Trotsenko, Y. A., McAnulla, C. \& Murrell, J. C. (2001). Hyphomicrobium chloromethanicum sp. nov. and Methylobacterium chloromethanicum sp. nov., chloromethaneutilizing bacteria isolated from a polluted environment. Int J Syst Evol Microbiol 51, 119-122.

McDonald, I. R., Warner, K. L., McAnulla, C., Woodall, C. A., Oremland, R. S. \& Murrell, J. C. (2002). A review of bacterial methyl halide degradation: biochemistry, genetics and molecular ecology. Environ Microbiol 4, 193-203.
Miller, L. G., Connell, T. L., Guidetti, J. R. \& Oremland, R. S. (1997), Bacterial oxidation of methyl bromide in fumigated agricultural soils. Appl Environ Microbiol 63, 4346-4354.

Page, R. D. M. (1996). TREEVIEW: an application to display phylogenetic trees on personal computers. Comput Appl Biosci 12, 357-358.

Schaefer, J. K. \& Oremland, R. S. (1999). Oxidation of methyl halides by the facultative methylotroph strain IMB-1. Appl Environ Microbiol 65, 5035-5041.

Schaefer, J. K., Goodwin, K. D., McDonald, I. R., Murrell, J. C. \& Oremland, R. S. (2002). Leisingera methylohalidivorans gen. nov., a marine methylotroph that grows on methyl bromide. Int J Syst Evol Microbiol 52, 851-859.

Tomasek, P. H. \& Karns, J. S. (1989). Cloning of a carbofuran hydrolase gene from Achromobacter sp. strain WM111 and its expression in gram-negative bacteria. J Bacteriol 171, 4038-4044.

Topp, E., Hanson, R. S., Ringelberg, D. B., White, D. C. \& Wheatcroft, R. (1993). Isolation and characterization of an $\mathrm{N}$ methylcarbamate insecticide-degrading methylotrophic bacterium. Appl Environ Microbiol 59, 3339-3349.

Topp, E., Zhu, H., Nour, S. M., Houot, S., Lewis, M. \& Cuppels, D. (2000). Characterization of an atrazine-degrading Pseudaminobacter sp. isolated from Canadian and French agricultural soils. Appl Environ Microbiol 66, 2773-2782.

Urakami, T., Araki, H., Oyanagi, H., Suzuki, K. \& Komagata, K. (1992). Transfer of Pseudomonas aminovorans (den Dooren de Jong 1926) to Aminobacter gen. nov. as Aminobacter aminovorans comb. nov. and description of Aminobacter aganoensis sp. nov. and Aminobacter niigataensis sp. nov. Int J Syst Bacteriol 42, 84-92. 